\title{
Delay in hip fracture surgery and its outcomes. A reflection
}

\author{
Retraso en cirugía de fractura de cadera y sus desenlaces. \\ Una reflexión

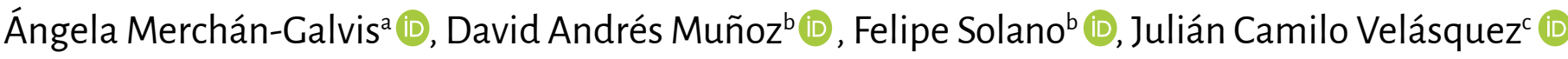 \\ a Department of Social Medicine and Family Health, School of Health Sciences, Universidad del Cauca. Popayán, Colombia \\ ${ }^{b}$ Department of Anesthesiology, School of Health Sciences, Universidad del Cauca. Popayán, Colombia \\ ' Department of Internal Medicine, School of Health Sciences, Universidad del Cauca. Popayán, Colombia
}

Correspondence: Departamento de Medicina Social y Salud Familiar, Facultad de Ciencias de la Salud, Universidad del Cauca, Cra 6\# 13N-50, piso 3, Popayán, Colombia. E-mail:angelamerchan@unicauca.edu.co

\section{What do we know about this problem?}

Delay in hip fracture surgery represents an increase in postoperative morbidity and mortality, a deterioration in the quality of life and functionality of the affected elderly.

Individual and external factors favor the delay in hip osteosynthesis.

\section{What is the contribution of this} study?

Review the state of the art regarding the delay of the osteosynthesis of the hip fracture and its outcomes.

Take a position on the factors that delay this type of surgery in the elderly population.

Suggests research alternatives in order to improve outcomes in the elderly population.
How to cite this article

Merchán-Galvis Á, Muñoz DA, Solano F, Velásquez JC. Delay in hip fracture surgery and its outcomes. A reflection. Colombian Journal of Anesthesiology. 2021;49(1):e915.

\section{Abstract}

Hip fracture is one of the major public healthcare problems in elderly patients around the world, mainly because of the risk of falls and osteoporosis which are typical during this stage of life, and may be the cause for up to $36 \%$ of deaths among those affected. Its management in principle is surgical and the best results are achieved with patients undergoing surgery during the first 24 to 72 hours after the fracture. Any delays in surgery are mostly associated with decompensated personal pathological factors, delays in perioperative assessment, or in presurgical complementary tests; sometimes, the delays are the result of administrative formalities of the healthcare providers. These determining factors may affect both morbidity and mortality, and contribute to functional decline, disability, and reduced quality of life of these patients. A third party intervention is then necessary to improve the preventable factors that delay the osteosynthesis in these types of fractures, in addition to ensuring education, infrastructure, inputs, skilled human resources, and prompt referral of patients from the first level of care. Investigating this scenario and assessing the quality of life impact on these patients should be a priority.

\section{Keywords}

Hip fracture; mortality; surgical delay; time-to-treatment; complications; quality of life.

\section{Resumen}

La fractura de cadera representa uno de los problemas de salud pública más grandes en los pacientes ancianos en todo el mundo, principalmente, por el riesgo de caídas y la osteoporosis típicos en esta etapa de la vida, que puede causar la muerte de hasta el $36 \%$ de los afectados; su manejo es en principio quirúrgico y los mejores resultados se presentan cuando se interviene en las primeras 24 a 72 horas después de la fractura. El retraso en la corrección quirúrgica está asociado principalmente a factores patológicos personales no compensados, demora en la valoración perioperatoria o en los estudios complementarios prequirúrgicos, o por trámites administrativos de las empresas prestadoras de servicios de salud. Estos determinantes pueden afectar la morbimortalidad y contribuir a un deterioro funcional, incapacidad y pérdida de la calidad de vida de estos pacientes. Se hace necesaria una intervención por parte de terceros para mejorar los factores prevenibles que retrasan la osteosíntesis de este tipo de fracturas; además, asegurar educación, infraestructura, insumos, talento humano capacitado y remisión rápida de pacientes desde el primer nivel de atención. Investigar en este escenario y evaluar los efectos en la calidad de vida de estos pacientes debería ser una prioridad.

\section{Palabras clave}

Fractura de cadera; mortalidad; retraso quirúrgico; tiempo de tratamiento; complicaciones; calidad de vida. 
Hip fracture (HF) is a severe public health problem affecting at least 1.5 million people each year around the world and it is expected to grow to around 2.6 million by $2025(1,2)$; furthermore, this number is expected to double between 2017 and 2050 , as a result of increased life expectancy. (3) Data from the International Osteoporosis Foundation estimate that among the women living in Colombia, around 8.000 to 10.000 hip fractures are reported per year, with a forecast of 11.500 for 2020; around $90 \%$ of these fractures shall be treated surgically. (4)

Latin America and the Caribbean are living through a phase of demographic transition, characterized by a decrease in the birth and mortality rates. This means, a reduction in child population and an increase in the elderly population, forecasting an $18 \%$ increase in the rate of the population over 65 years old. In Colombia, the population over 65 years represents $7.68 \%$ of the total population; in other words, a 1.42 percentage points increase with regards to 2005 and it is expected that for 2020 the proportion continues to rise up to $8.50 \%$. (5) This will clearly increase the incidence of HF in our country.

Though hip fractures are infrequent before sixty years of age, and are very rare among youth, its incidence approaches $2 \%$ of the total number of fractures and is associated with professional risks or driving vehicles that result in high energy trauma. There are two major risk factors that contribute to the incidence of $\mathrm{HF}$ among the elderly: osteoporosis and falls from standing, the latter being the most frequent. There are other conditions that promote the development of this type of fractures, such as neuromuscular changes, medicines affecting stability or alertness, neurological diseases, loss of visual acuity, middle ear disorders, dementia, inter alia. These conditions, in addition to increasing the risk of falls, hinder the defense mechanisms against falling, leading to a more significant impact and severity. (6)

HF represents one of the major causes of morbidity, disability, functional decline, and mortality among the elderly, leading to high costs for the public health system.
The direct hospital cost involved in treating a hip fracture is estimated at USD $\$ 6,457$. The average hospital stay per patient with this type of fracture is 10 days, with the subsequent loss of independence to conduct their daily life activities, and almost $50 \%$ of the patients admitted from home, need a change of residence upon discharge. (1)

Among the elderly population of the United States, HF accounts for a one-year mortality ranging from 14 to $36 \%$. Around $7.5 \%$ of the patients affected die during the first 30 days after the fracture, two thirds of these will die in the hospital, and one third after discharge. In England, $10.9 \%$ of the patients admitted with hip fractures died 30 days after the date of admission (7) and approximately 12 to $37 \%$ of them will die within one year after surgery. The risk of mortality depends to a large extent on the individual characteristics of each patient, the extent of the injury, the comorbidities and treatment. (8)

The treatment for hip fracture is usually surgical and when the procedure is delayed, up to $8 \%$ of the cases become deeply depressed and $15 \%$ will experience higher anesthetic and surgical risk when previous similar fractures have been sustained. The time elapsed between diagnosis and treatment considerably impacts the survival of patients, since per every two days waiting for surgery, the probability of dying from secondary complications such as pulmonary thromboembolism, hydroelectrolytic imbalance, stroke, congestive heart failure, gastrointestinal bleeding, pneumonia and other respiratory diseases, urinary tract infections, pressure sores, rejection of the osteosynthesis material, and additional surgical site infection that may even lead to the removal of the osteosynthesis material, doubles. All of the above involves a strong impact on functionality and quality of life $\underline{(6,9)}$, and translates into extended hospital stay and longer antibiotic therapy.

With regards to the exact timing for surgical management of these fractures, mortality rates of up to $13 \%$ have been reported in developing countries for delays of surgery of up to eleven days. (2) However, the recommendation is to perform the surgery during the first 24-72 hours; some countries have established to do the procedure during the first 48 hours of admission to the hospital, which is considered a quality indicator for their hospitals. (6) A study conducted in Bogotá found a reduction of around 5 hospitalization days and lower acute postoperative morbidity among patients who underwent surgery during the first 48 hours. (3) Likewise, there are trials showing that hip osteosynthesis that lasts more than 24 hours is associated with a higher risk of complications and increased costs; however, only one third of the patients undergo surgery before this timeline. $(10,11)$ In this regard, some authors have compared the outcomes in patients that underwent surgery during the first 6 to 24 hours after admission, and reported that there are no differences in terms of mortality and major complications $(11,12)$; this suggests that the first hospital day may be enough to study and decide the surgical approach in this type of patients.

Sometimes, the speed at which surgery is performed, depends among other variables on the preoperative assessment, the need to stabilize any chronic underlying conditions of the patient, and in our setting, the complex and burdensome formalities to get the authorization for the osteosynthesis materials, supplies, and other medical procedures that in the end hinder a timely intervention of the patient. $(6,13)$ Adult cardiovascular, cerebral or respiratory comorbidities, age, gender, type of fracture, bone quality, and surgical delay, are all predictors affecting the outcomes of these patients. (8)

Data obtained from the Canadian Institute of Health Information, indicate that in general, $6.7 \%$ of the patients undergoing surgery, present with a medical condition that may delay surgery; among these conditions, the predominant pathology is the exacerbation of a chronic pulmonary disease. (14) In contrast, a study conducted in Bogotá reported a delay of surgery of 8.8 days mostly associated with a 
Charlson comorbidity index $\geq 3$, age over 80 years old and hemoglobin less than $10 \mathrm{~g} / \mathrm{dL}$; on top, there is also issue of patient referrals between hospitals due to administrative formalities or due to the need for a higher level of care, admissions during weekends and holidays, availability of OR, shortage of beds for hospitalization, and the voluntary delay of the patient to see the doctor. The conclusion is that a delay of more than four days in the surgical correction of the hip fracture, is associated with increased mortality at 30 days, 6 months, and one year after surgery, with rates of $14 \%, 24 \%$ and $31 \%$, respectively. (2)

Colombia in number three in the list of countries with more delays to complete the formalities in America; it is estimated that in average the process may take at least 20 days, and that every 52 seconds a Colombian citizen introduces a writ for the protection of constitutional health rights (15); hence, all these formalities and significant delays in hospitalization processes, including those associated with hip fractures, in the end compromise the life of the patient. It is then necessary for the State to take urgent steps in order to reduce these significant delays. It is a must that the institutions involved take responsibility in caring for patients promptly, in addition to implementing the corresponding control and evaluation of noncommittal actions of these institutions to optimize the response to the management of hip fractures.(16)

Although hospital delays may be an obstacle in caring for this condition, there is also a significant delay in the primary care provided to patients in the rural areas; patients who live in very remote regions, far from primary care centers and additionally have a strong influence of traditional medicine and sometimes are even illiterate, and this hinders a proper understanding of the care instructions, is a limitation to expressing their needs to healthcare providers and early delivery of emergency services. (17)

It should be highlighted that in our healthcare system, the municipal institutions apparently lack the capacity to meet the needs of a growingly aging population (16), susceptible to present with this type of fractures that require priority care. Very often, this hinders the achievement of the treatment objectives in terms of the time elapsed between the event and the surgical intervention, with a negative impact on the rate of postoperative medical complications associated with the delay in surgery, including death. (18) It is therefore necessary to strike a balance between optimizing medical care and early surgery, especially in a third world country evidencing a lack of investment to ensure the necessary infrastructure to meet the needs of the population, slow referral of rural patients, shortage of supplies, medicines, hospital beds, shortage of intensive care units, of operating rooms, and of human resources. $(15,16)$ All of these challenges need to be tackled in order to deliver comprehensive and good quality care to patients with hip fractures.

There are few papers published in Colombia desribing the epidemiological characteristics, the time estimated from admission to surgery, the mortality at 30 days, and the effects of delaying surgery; neither are there any studies aimed at establishing the impact of all of the above, on the quality of life of these patients. Therefore, it is then critical to produce this type of evidence to implement action plans and strategies designed to improve outcomes in our elderly population.

\section{ACKNOWLEDGEMENTS}

\section{Contributions by the authors}

AM: Inception, structure, writing, review and final approval of the document.

DM, FS y JV: Inception, writing, review ad final approval of the document.

\section{Assistance to conduct the study}

None declared.

\section{Financial support and sponsorship}

None declared.

\section{Conflict of interests}

None declared.

\section{Acknowledgements}

Ángela Merchán, nominee to a PhD degree on Methodology for Biomedical Research and Public Health, Universidad Autónoma de Barcelona, Spain.

\section{REFERENCES}

1. Anthony CA, Duchman KR, Bedard NA, Cholson J], Gao Y, Pugely A], et al. Hip fractures: appropriate timing to operative intervention. ] Arthroplasty. 2017;32(11):3314-8. DOI: https:// doi.org/10.1016/j.arth.2017.07.023

2. Espinosa KA, Gélvez AG, Torres LP, García MF, Peña OR. Pre-operative factors associated with increased mortality in elderly patients with a hip fracture: A cohort study in a developing country. Injury. 2018;49(6):1162-8. DOI: https://doi.org/10.1016/j.injury.2018.04.007

3. Morales Ó, Parra JD, Mateus R. Morbimortalidad posterior a fracturas intertrocantéricas de cadera. Efecto del retraso en el tratamiento quirúrgico. Rev Colomb Ortop Traumatol. 2018;32(1):33-7. DOI: https://doi.org/10.1016/j. rccot.2017.07.005

4. International Osteoporosis Foundation. The Latin America Regional Audit. Colombia [Internet]. 2012 [citado: 22 de octubre de 2018]. Disponible en: https://www.iofbonehealth. org/sites/default/files/media/PDFs/Regional\%20Audits/2012-Latin_America_Audit-Colombia-ES_o_o.pdf

5. Ministerio de Salud, Dirección de Epidemiología y Demografía. Análisis de Situación de Salud (ASIS) [Internet]. 2016 [citado: 22 de octubre de 2018]. Disponible en: https://www. minsalud.gov.co/salud/publica/epidemiologia/Paginas/analisis-de-situacion-de-salud-. $\underline{\text { aspx }}$

6. Negrete-Corona ], Alvarado-Soriano JC, Reyes-Santiago LA. Fractura de cadera como 
factor de riesgo en la mortalidad en pacientes mayores de 65 años. Estudio de casos y controles. Acta Ortopédica Mex. 2014;28(6):352-62.

7. Sayers A, Whitehouse MR, Berstock JR, Harding KA, Kelly MB, Chesser T]. The association between the day of the week of milestones in the care pathway of patients with hip fracture and 30-day mortality: findings from a prospective national registry-The National Hip Fracture Database of England and Wales. BMC Med. 2017;15(1):62. DOI: https://doi. org/10.1186/s12916-017-0825-5

8. Sheehan K], Sobolev B, Villán YFV, Guy P. Patient and system factors of time to surgery after hip fracture: a scoping review. BM] Open. 2017;7(8):e016939.

9. Suárez Monzón H, Arniella Y, Ángel L, Quintana López B. Impacto de los diferentes factores acerca de la sobrevida en pacientes con fractura de cadera. Rev Cuba Ortop Traumatol. 2016;30(1):8-26.

10. Pincus D, Wasserstein D, Ravi B, Byrne JP, Huang $A$, Paterson JM, et al. Reporting and evaluating wait times for urgent hip fracture surgery in Ontario, Canada. CMAJ. 2018;190(23):E702-9. DOI: https://doi.org/10.1503/cmaj.170830
11. Kristiansson ], Hagberg E, Nellgård B. The influence of time-to-surgery on mortality after a hip fracture. Acta Anaesthesiol Scand. 2020;64(3):347-53. DOI: https://doi. org/10.1111/aas.13494

12. Borges FK, Bhandari M, Guerra-Farfan E, Patel A, Sigamani A, Umer $M$, et al. Accelerated surgery versus standard care in hip fracture (HIP ATTACK): an international, randomised, controlled trial. The Lancet. 2020;395(10225):698-708. DOI: https://doi. org/10.1016/S0140-6736(20)30058-1

13. Cha Y-H, Ha Y-C, Yoo J-I, Min Y-S, Lee Y-K, $\mathrm{Koo} \mathrm{K}-\mathrm{H}$. Effect of causes of surgical delay on early and late mortality in patients with proximal hip fracture. Arch Orthop Trauma Surg. 2017;137(5):625-30. DOI: https://doi. org/10.1007/s00402-017-2674-2

14. Guy P, Sheehan K], Morin SN, Waddell ], Dunbar M, Harvey E, etal. Feasibility of using administrative data for identifying medical reasons to delay hip fracture surgery: a Canadian database study. BM] Open. 2017;7(10):e017869. DOI: 10.1136/bmjopen-2017-017869
15. Suárez-Rozo LF, Puerto-García S, Rodríguez-Moreno LM, Ramírez-Moreno ]. La crisis del sistema de salud colombiano: una aproximación desde la legitimidad y la regulación. Rev Gerenc Políticas Salud. 2017;16(32):34-50. DOI: http://dx.doi.org/10.11144/javeriana. rgps16-32.cssc

16. Molina-Marín G, Vargas-Jaramillo ], Berrío-Castaño A, Muñoz-Marín DP. Características de la contratación entre aseguradores y prestadores de servicios de salud, Medellín, 2007-2008. Gerenc Políticas Salud. 2010;9(18). DOI: https://doi.org/10.11144/Javeriana.rgsp918.ccea

17. Russo M. Estudio exploratorio del impacto del alfabetismo funcional sobre conductas sanitarias deficientes a nivel poblacional. Rev Médica Chile. 2015;143(7):856-63. DOI: http://dx. doi.org/10.4067/S0034-98872015000700005

18. Sanz-Reig ], Salvador Marín ], Ferrández Martínez ], Orozco Beltrán D, Martínez López JF. Factores de riesgo para la demora quirúrgica en la fractura de cadera. Rev Esp Cir Ortopédica Traumatol. 2017;61(3):162-9. DOI: https:// doi.org/10.1016/j.recot.2017.02.001 